\title{
Pemberdayaan Lansia Produktif, Aktif, Sehat Melalui Promosi Kesehatan dan Pemanfaatan Tanaman Obat di Desa Bumiharjo Kecamatan Glenmore Kabupaten Banyuwangi
}

\author{
Yeni Andriani, Vita Raraningrum, Reni Sulistyowati \\ Prodi DIII Kebidanan Akademi Kesehatan Rustida \\ yeenni01@gmail.com
}

\begin{abstract}
Abstrak
Desa Bumiharjo merupakan salah satu desa yang terletak di Kecamatan Glenmore Kabupaten Banyuwangi yang membawahi 3 dusun yaitu Dusun Wonoasih, Dusun Sugih Waras dan Dusun Balerejo. Penduduk Desa Bumiharjo sebagian besar merupakan lansia. Lansia di Desa Bumiharjo mayoritas berpendidikan rendah, yaitu hanya lulusan SD, sehingga sebagian besar bekerja sebagai buruh tani dan rata-rata penghasilannya sangat jauh dibawah Upah Minimum Regional (UMR) Kabupaten Banyuwangi. Program kemitraan masyarakat (PKM) ini bertujuan untuk memberikan penguatan pada program posyandu lansia di Desa Bumiharjo, dengan memberikan pendidikan kesehatan, mengajari senam lansia dan membudidayakan serta memanfaatkan tanaman obat keluarga. Kegiatan ini dilaksanakan dalam bentuk promosi kesehatan melalui pemberian pendidikan kesehatan penyakit tidak menular yang sering dialami oleh lansia serta cara pencegahan dan penanggulangannya dengan memanfaatkan tanaman obat keluarga. Metode yang digunakan adalah ceramah disertai tanya jawab dengan media leaflet. Hasil program ini yaitu pelaksanaan kegiatan PKM secara garis besar sudah cukup baik (80\%). Promosi kesehatan berupa pemberian pendidikan kesehatan efektif digunakan untuk meningkatkan pengetahuan lansia, senam lansia untuk meningkatkan keaktifan fisik dan pemanfaatan tanaman obat keluarga untuk menjaga kesehatan lansia dengan bahan-bahan yang alami serta dalam jangka panjang mampu meningkatkan derajat kesehatan dan usia harapan hidup lansia.
\end{abstract}

Kata Kunci: Lansia, Pemberdayaan, Tanaman Obat

\begin{abstract}
Bumiharjo Village is one of the villages located in Glenmore Sub-district, Banyuwangi Regency which is in charge of 3 hamlets, namely, Wonoasih Hamlet, Sugih Waras Hamlet, and Balerejo Hamlet. Most of the residents of Bumiharjo Village are elderly. Elderly people in the village of Bumiharjo has a low level of education, which is only collecting elementary school, more work as farm laborers and the average is higher than the Regional Minimum Wage (UMR) of Banyuwangi Regency. This community partnership program (PKM) supports the elderly posyandu program in Bumiharjo Village, provides health education, teaches elderly gymnastics and cultivates and utilizes family medicinal plants. This activity is carried out in the form of health promotion through the implementation of non-communicable health education that is often attended by the elderly as well as ways to prevent and utilize family medicinal plants. The method used is question and answer with media leaflets. The result of this program is that the activities carried out by PKM in general have been quite good (80\%). Health promotion consisting of effective health education is used to increase the knowledge of the elderly, elderly gymnastics to improve physical activity and the use of medicinal plants to improve the health of the elderly with natural ingredients and in improving health and the elderly.
\end{abstract}

Keywords: Elderly, Empowerment, Medicinal Plants 


\section{PENDAHULUAN}

Lanjut usia (lansia) adalah seseorang yang telah mencapai usia lebih dari 60 tahun (UU, 1998). Keberhasilan pembangunan di berbagai bidang terutama bidang kesehatan menyebabkan terjadinya peningkatan Usia Harapan Hidup (UHH) penduduk dunia termasuk Indonesia. Namun, dibalik peningkatan UHH terselip tantangan yang harus diwaspadai yaitu ke depannya Indonesia akan menghadapi beban tiga (triple burden) yaitu disamping meningkatnya angka kelahiran dan beban penyakit (menular dan tidak menular), juga akan terjadi peningkatan angka beban tanggungan penduduk kelompok usia produktif terhadap kelompok usia tidak produktif.

Proses penuaan akan berdampak pada berbagai aspek kehidupan, baik sosial, ekonomi, maupun kesehatan. Ditinjau dari aspek kesehatan, dengan semakin bertambahnya usia maka lansia lebih rentan terhadap berbagai keluhan fisik, karena faktor alamiah maupun karena faktor penyakit. Angka kesakitan merupakan salah satu indikator yang digunakan untuk mengukur derajat kesehatan penduduk. Angka kesakitan lansia merupakan proporsi masalah kesehatan hingga mengganggu aktivitas sehari-hari selama satu bulan terakhir. Menurut Kemenkes (2014), angka kesakitan lansia di daerah perkotaan dan pedesaan pada tahun 2008-2012 menunjukkan bahwa angka kesakitan lansia di daerah perkotaan cenderung lebih rendah dibandingkan dengan daerah pedesaan, artinya derajat kesehatan lansia di daerah perkotaan relatif lebih baik dibandingkan dengan lansia yang tinggal di daerah pedesaan.

Desa Bumiharjo merupakan salah satu desa yang terletak di Kecamatan Glenmore Kabupaten Banyuwangi. Secara administratif, Desa Bumiharjo membawahi 3 dusun yaitu Dusun Wonoasih, Dusun Sugih Waras dan Dusun Balerejo. Desa Bumiharjo memiliki jumlah penduduk sebanyak 7.183 jiwa yang terdiri dari jenis kelamin laki-laki sebanyak 3.487 jiwa dan jenis kelamin perempuan sebanyak 3.700 jiwa. Penduduk Desa Bumiharjo sebagian besar merupakan lansia. Lansia di Desa Bumiharjo mayoritas berpendidikan rendah, yaitu hanya lulusan SD, sehingga sebagian besar bekerja sebagai buruh tani, dan sangat jarang sebagai pensiunan Pegawai Negeri Sipil (PNS) sehingga rata-rata penghasilannya sangat jauh dibawah Upah Minimum Regional (UMR) Kabupaten Banyuwangi.

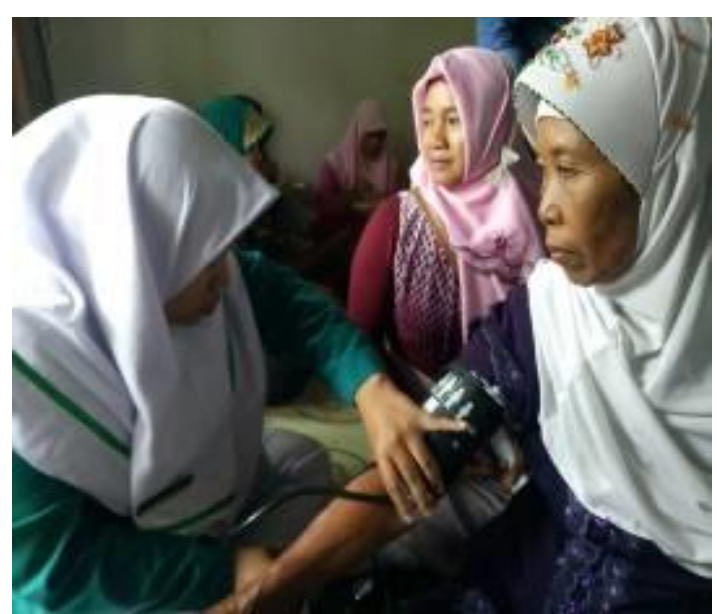

Gambar 1 Lansia sedang melakukan pemeriksaan tekanan darah

Kualitas produktivitas lansia menurun karena terjadi proses penuaan (aging) yang berarti sebagian besar sistem organ mengalami kehilangan atau penurunan fungsi $1 \%$ setiap tahun. Hal ini menyebabkan masalah kesehatan banyak bermunculan pada kaum lansia. Kegiatan kemitraan masyarakat ini bertujuan untuk memberikan penguatan 
pada program posyandu lansia di Desa Bumiharjo, dengan memberikan pendidikan kesehatan, mengajari senam lansia dan membudidayakan serta memanfaatkan tanaman obat keluarga.

\section{MATERI DAN METODE}

Kegiatan ini dilaksanakan mulai bulan Mei 2018 sampai Desember 2018 di Desa Bumiharjo Kecamatan Glenmore Kabupaten Banyuwangi. Metode yang digunakan dalam pelaksanaan program ini yaitu tahap perencanaan, pelaksanaan, observasi dan evaluasi.

\section{A. Perencanaan}

Dalam tahap perencanaan, tim program PKM akan melakukan pertemuan antara Kepala Desa Bumiharjo, Kepala Puskesmas Tulungrejo dan Bidan wilayah untuk merencanakan dan membuat perangkat yang digunakan, misalnya menyusun jadwal rutin posyandu lansia, pembuatan daftar hadir peserta posyandu lansia, pembuatan leaflet dan modul.

\section{B. Pelaksanaan}

Pada tahap pelaksanaan, tim program PKM melakukan kegiatan musyawarah dengan mitra (Desa Bumiharjo), Bidan wilayah, kader posyandu lansia untuk menentukan lokasi kegiatan, memasang banner di lokasi kegiatan, saat posyandu lansia selalu melakukan promosi kesehatan baik berupa pemberian pendidikan kesehatan maupun praktik senam lansia, membagikan tanaman obat keluarga dan mempraktikkan pembudidayaan tanaman obat keluarga dengan memanfaatkan lahan kosong.

\section{Observasi}

Dalam tahap observasi, selalu melakukan posyandu lansia rutin setiap 1 bulan sekali, tim PKM bersama Kepala Desa, Kepala Puskesmas, Bidan wilayah serta kader posyandu tetap melakukan pemantauan kegiatan.

\section{Evaluas}

Pada tahap akhir, yaitu tahap evaluasi dilakukan setiap akhir kegiatan program dan dilakukan sebanyak 2 kali saat pertemuan terakhir, yaitu pada pertemuan Bulan November dan Desember, evaluasi dilakukan dengan melihat dokumentasi setiap kegiatan dan daftar hadir peserta yang > 5 kali kehadiran serta melihat Kartu Menuju Sehat (KMS) lansia, evaluasi peningkatan pengetahuan dapat dilakukan dengan memberikan pertanyaan kepada lansia dan semua pertanyaan tersebut dapat dijawab serta dapat dijelaskan dengan tepat, evaluasi kegiatan dapat dilakukan dengan memperhatikan kesehatan lansia, misalnya pada lansia banyak yang tidak mengalami peningkatan tekanan darah dan evaluasi kegiatan dapat dilakukan dengan melihat kesuburan tanaman obat keluarga yang sudah ditanam serta hasilnya dapat dijual untuk menambah penghasilan lansia.

\section{HASIL DAN PEMBAHASAN}

Kegiatan-kegiatan yang telah dilakukan adalah:

1. Tim Program Kemitraan Masyarakat (PKM) telah melakukan pertemuan/musyawarah antara Kepala Desa Bumiharjo, Kepala Puskesmas Tulungrejo dan Bidan wilayah untuk merencanakan kegiatan pengabdian masyarakat misalnya terkait lokasi dilakukannya kegiatan, penyusunan jadwal rutin posyandu lansia, tema dalam pendidikan kesehatan, pembuatan leaflet serta 
pembuatan daftar hadir peserta. Hasil kesepakatan adalah kegiatan posyandu lansia dilakukan pada tiap dusun yang ada di Desa Bumiharjo yaitu Dusun Balerejo, Dusun Sugih Waras dan Dusun Wonoasih. Kegiatan posyandu lansia di Dusun Balerejo dilakukan pada hari Sabtu minggu pertama dan Sabtu minggu kedua, untuk Dusun Sugih Waras dijadwalkan pada hari Kamis minggu ketiga serta di Dusun Wonoasih dijadwalkan pada hari Sabtu minggu ketiga. Semua lokasi kegiatan yaitu di rumah kader lansia. Tema pemberian pendidikan kesehatan adalah tentang penyakit tidak menular yang sering dialami oleh lansia.

2. Melakukan sosialisasi akan dilakukannya kegiatan pengabdian kepada masyarakat kelompok lanjut usia.

3. Memasang banner di lokasi kegiatan, yang bertujuan untuk mempermudah lansia menemukan lokasi kegiatan.

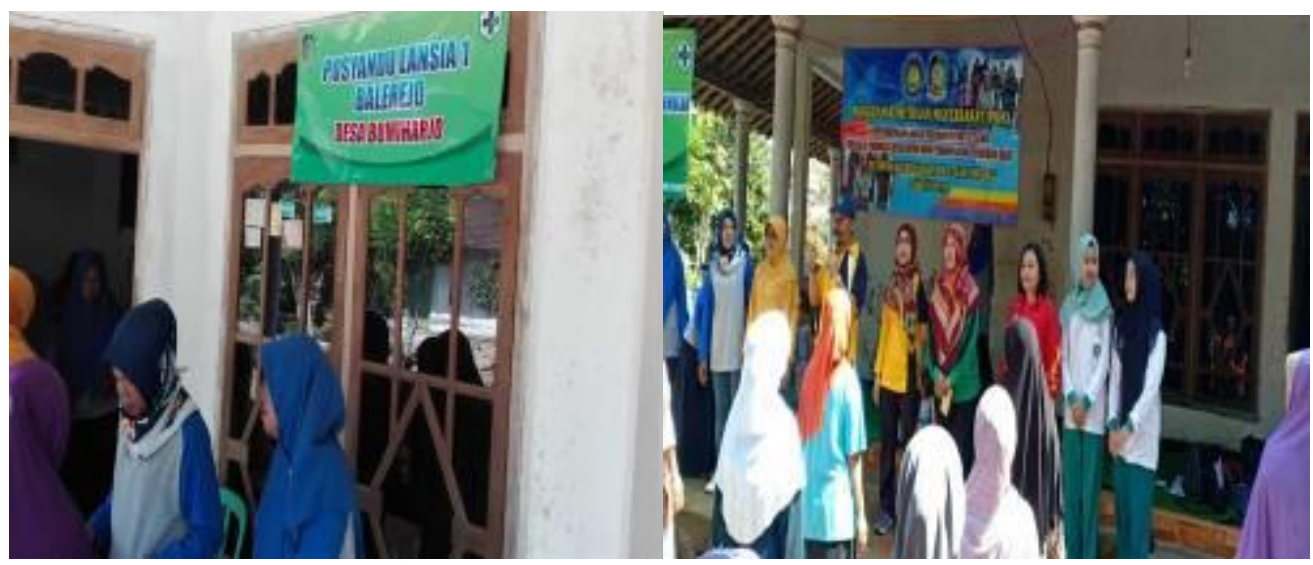

Gambar 2 Pemasangan banner di lokasi kegiatan

4. Pada setiap kegiatan posyandu lansia melakukan promosi kesehatan baik berupa pemberian pendidikan kesehatan maupun praktik senam lansia. Kegiatan posyandu lansia minimal diikuti oleh 35 orang.

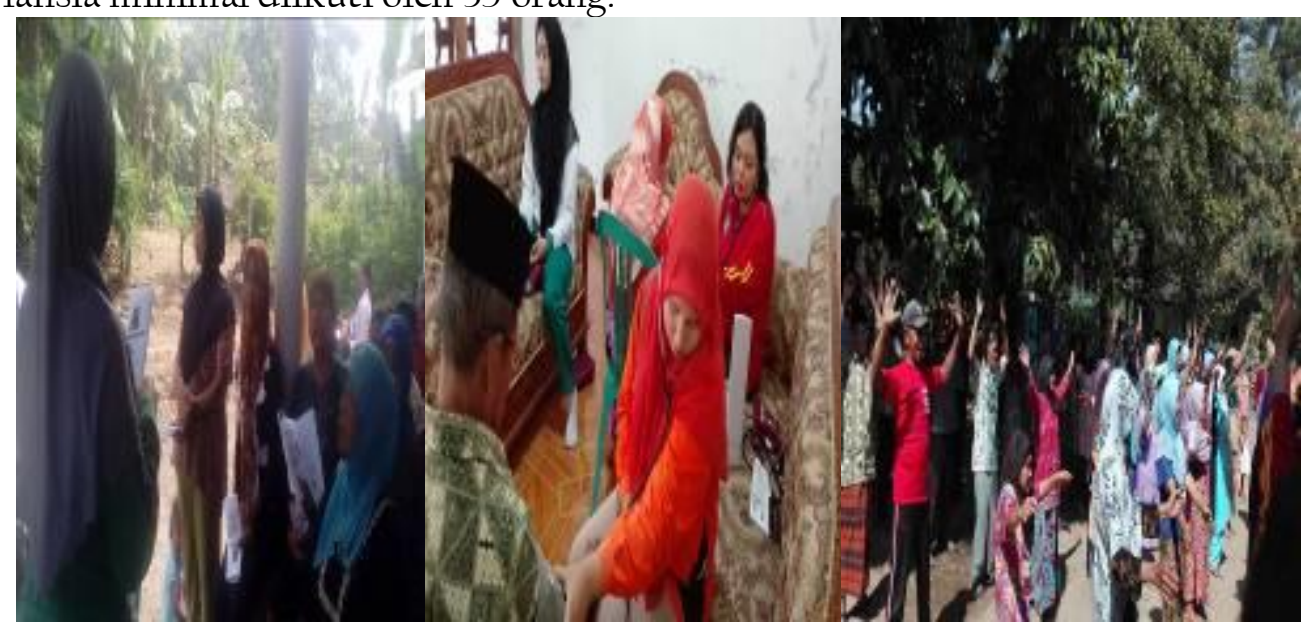

Gambar 3 Kegiatan posyandu lansia

5. Pendidikan kesehatan yang dapat diberikan misalnya tentang cara hidup sehat dan informasi mengenai penyakit tidak menular maupun gejala yang sering diderita oleh lansia yaitu tekanan darah tinggi, kencing manis, mudah lelah, katarak, dan gejala penyakit yang lain serta manfaat tanaman obat keluarga untuk pencegahan 
penyakit tersebut. Narasumber kegiatan ini adalah tim Program Kemitraan Masyarakat (PKM) yang digilir dan mempunyai kesempatan yang sama untuk memberikan materi tentang kesehatan.

6. Membagikan tanaman obat keluarga kepada lansia dan praktik pembudidayaan tanaman obat keluarga dengan memanfaatkan lahan kosong. Tanaman obat yang telah dibagikan misalnya bibit jahe, kunyit, temulawak, dan lain sebagainya.

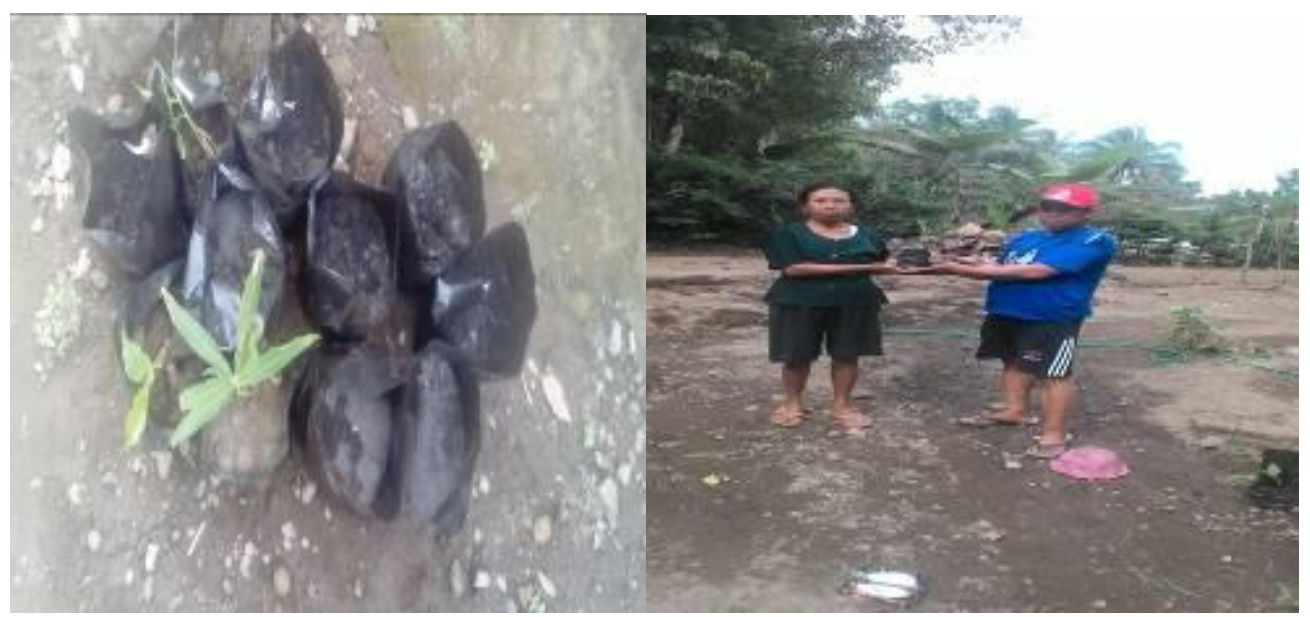

Gambar 4 Pembagian tanaman obat keluarga kepada lansia

7. Hasil pelaksanaan kegiatan PKM secara garis besar sudah cukup baik (80\%).

Hasil evaluasi ini dapat dilihat berdasarkan komponen :

a. Ketercapaian tujuan PKM

Ketercapaian tujuan PKM dapat dikatakan cukup baik (80\%). Dengan adanya pemberian pendidikan kesehatan pada setiap kegiatan posyandu lansia dapat meningkatkan pengetahuan lansia tentang kesehatan terutama penyakit tidak menular yang sering dialami, senam lansia untuk meningkatkan keaktifan fisik dan pemanfaatan tanaman obat keluarga untuk menjaga kesehatan lansia dengan bahan-bahan yang alami serta mencegah dan mengobati penyakit tidak menular. Evaluasi pengetahuan dilakukan dengan cara memberikan pertanyaan kepada lansia dan semua pertanyaan tersebut dapat dijawab serta dapat dijelaskan dengan tepat, misalnya tentang cara hidup sehat dan cara pencegahan penyakit. Pada saat dilakukan pengukuran tekanan darah, kasus darah tinggi sudah mulai berkurang.

b. Kehadiran peserta

Kehadiran peserta pada kegiatan posyandu lansia sudah baik (85\%). Lansia di Desa Bumiharjo memiliki motivasi yang tinggi untuk mengikuti kegiatan posyandu lansia dengan kehadiran setiap kegiatan minimal diikuti oleh 35 orang dan setiap orang hadir $>5$ kali.

c. Pertumbuhan tanaman obat keluarga

Pertumbuhan tanaman obat keluarga sudah cukup baik (70\%). Tanaman obat keluarga dapat tumbuh dengan subur dan dimanfaatkan untuk menjaga kesehatan serta mencegah dan mengobati berbagai penyakit tidak menular pada lansia.

8. Pelaksanaan program kemitraan masyarakat secara keseluruhan sudah cukup baik yang dapat diukur dari beberapa komponen diatas. Dalam jangka panjang, program 
ini bertujuan untuk meningkatkan derajat kesehatan dan usia harapan hidup lansia.

\section{KESIMPULAN DAN SARAN}

A. Kesimpulan

Pelaksanaan program kemitraan masyarakat (PKM) ini dapat disimpulkan bahwa promosi kesehatan berupa pemberian pendidikan kesehatan efektif digunakan untuk meningkatkan pengetahuan lansia, senam lansia untuk meningkatkan keaktifan fisik dan pemanfaatan tanaman obat keluarga untuk menjaga kesehatan lansia dengan bahan-bahan yang alami serta dalam jangka panjang mampu meningkatkan derajat kesehatan dan usia harapan hidup lansia.

\section{B. Saran}

1. Program PKM ini diharapkan dapat ditindaklanjuti di lokasi lain untuk meningkatkan pengetahuan tentang penyakit tidak menular yang sering dialami oleh lansia dan memanfaatkan tanaman obat keluarga sebagai upaya pencegahan dan pengobatan penyakit serta dapat dijual untuk menambah pendapatan keluarga.

2. Adanya penambahan materi tentang manajemen pemasaran tanaman obat keluarga.

\section{DAFTAR PUSTAKA}

Kementerian Kesehatan RI. 2014. Situasi dan Analisis Lanjut Usia. Jakarta : Infodatin Pusat Data dan Informasi Kementerian Kesehatan RI.

Mahasiswa Semester V Prodi DIII Kebidanan Akademi Kesehatan Rustida. 2018. Laporan Asuhan Kebidanan Komunitas Desa Bumiharjo.

Sagoro, L., Fathori, A, dkk. 2014. Puntadewa: Pemberdayaan Lansia Produktif, Aktif dan Sehat, program Peningkatan Kualitas Hidup Lansia Melalui Promosi Kesehatan serta Pelatihan Pemanfaatan Tanaman Obat. Yogyakarta: Universitas Gadjah Mada Yogyakarta.

Undang-Undang Nomor 13 Tahun 1998 Tentang Kesehatan. 